\title{
Introduction to Special Issue SI: Luhmann
}

\author{
Claudius Messner
}

Published online: 28 December 2013

(C) Springer Science+Business Media Dordrecht 2013

This year marks the 30th anniversary of the publication of Niklas Luhmann's (1927-1998) magnum opus Soziale Systeme. Grundriss einer allgemeinen Theorie [14]. On the occasion, this Special Issue of the International Journal for the Semiotics of Law celebrates the contribution of Luhmann's thinking to our understanding of law, justice, and society.

Luhmann's work is wide open for argument. Some consider it the grand unified theory able to completely grasp social reality. Others see nothing but a substantially void conglomeration of analytical constructs and "behaviouristic" descriptions joined together with "pseudo-empirism" [24, pp. 310, 313] or a hermetic ensemble of "self-mystifying semantics" [7, p. 76] supported by sophisticated strategies of pure self-apology. It might seem that the "giant" [1] theorist of the social has encouraged such impressions with pretensions which were "grandiose" in more than one respect $[9,23]$. Indeed, readers who encounter systems theory for the first time may find that an understanding of Luhmann's complex theory is complicated by a string of conceptual and semantic barriers as well as the hurdles of Luhmann's habitually ironic, sometimes authoritative, and sometimes counter intuitive style. An often shared reading experience is, as a German commentator notes, that "texts appear convincing only after 300-500 pages" [20, p. 13]. Another finds consolation with the difficulties of reading Luhmann in considering that, given that Luhmann's is a perfectly new theory, no previous experience is needed to access it [21, p. 522]. Possibly because of the combined effects of the difficulties of reading Luhmann and his writings not being widely translated, the reception of his oeuvre in the Englishspeaking world is still localised [4, 22], whereas it has a substantial following in Germany and continental Europe. Nonetheless, the interdisciplinary impact of

C. Messner (ه)

Dipartimento di Scienze Giuridiche, Università del Salento, 73100 Lecce, Italy

e-mail: claudius.messner@unisalento.it 
systems theory shows results in a variety of disciplines such as sociology, law, economics, politics, administration studies, and cultural studies. Recent years have seen, after the 2004 publication in English of Law as a Social System, a growing interest in legal research on or under the methodological influence of Luhmann [6].

Luhmann's work, however, is also wide open for meditation. To be sure, not of the kind of exegetical thinking that, unable to argue from outside the theory, defends Luhmann from within. We don't need a scholasticism of Luhmann. His conceptual abstractions, analytical strategies, and discursive gestures require critical reflection. Luhmann's argumentation wishes to be followed and used for observing, through it, what is said, what is left unsaid, and what has been ignored. Luhmann's "supertheoretical" [19, p. 5] enterprise invites opposition. Beyond myth-making around the author and hypostatising systems theory as the beginning and end of any scientific approach, neither social theory nor legal theory nor other disciplines can afford to avoid the challenge posed by Luhmann's work. Much like Michel Foucault, Luhmann is a central figure in the contemporary theoretical landscape. One cannot get out of deciding on if and how to argue with him. The best way to take Luhmann seriously, it seems to me, is to pose questions on his theory's premises, claims and implications. So, the only brief to contributors was to read Luhmann "against the grain".

But, before going on to this collection, let me spend some space here on the theoretical project which Luhmann "offered under the brand name "systems theory" " [14, p. xxxvii]. For the purposes of an introduction, I will confine myself to three aspects: the construction of the theory of society as reflected in Luhmann's publication policy; its 'ambitiously modest' [5] claim to universality; and its presumed radical break with traditional thinking. These rather general remarks might suggest some reason why I believe that like all myths also the one about Luhmann the light-bearing herald of the dawn has some truth to it.

\section{I}

Following the author's hints [12, p. 1, 13, pp. 11-13, 16], one can roughly subdivide the production of Luhmann's theory in three phases: (1) the preliminary series ("Nullserie") which begins in the middle of the 1960s and ends, in 1984, with the "first proper publication", Social Systems [16, p. 142], (2) a series of analyses of individual functional systems, and (3) the closing of the project in 1997 with the grand final book on society as a social system, Die Gesellschaft der Gesellschaft. This executive sequence corresponds perfectly to the plan of the theoretical edifice the architect said he had in mind "from the very start" [13, p. 11]. ${ }^{1}$ If this implies a relative straightness and constancy of Luhmann's production over the entire period

\footnotetext{
1 There is no note of false modesty in Luhmann's words which, as Descartes had it in 1637, invite to “considérer que souvent il n'y a pas tant de perfection dans les ouvrages composés de plusieurs pièces, et faits de la main de divers maîtres, qu'en ceux auxquels un seul a travaillé. Ainsi voit-on que les bâtiments qu'un seul architecte a entrepris et achevés ont coutume d'être plus beaux et mieux ordonnés que ceux que plusieurs ont tâché de raccommoder, en faisant servir de vieilles murailles qui avaient été bâties à d'autres fins": Discours, Seconde partie: principales règles touchant les sciences.
} 
of nearly 40 years, the thesis of Luhmann's “autopoietic turn" in 1984 must be qualified.

The nearly 700 pages of Soziale Systeme. Grundriss einer allgemeinen Theorie appeared as an "introduction" $[12$, p. 1, 13, p. 11] to a theory of society still to be written. The "chapter" was not meant to represent the final answer to the theoretical problems Luhmann had been addressing previously. Moreover, the book can well be considered as Luhmann's Discours de la méthode in that it provides a coherent context which reflects his specific way of posing questions and defines (with reference to systems theoretical insights from various disciplines) ${ }^{2}$ concepts and distinctions (such as system and environment, structure and time, closure and openness, contingency, meaning, communication, and self-reference) which remain fundamental principles of the whole work. In particular, Luhmann was able to integrate a notion of autopoiesis abstracted from all biological connotations precisely because his conceptual frame of reference had always been oriented by "self-reference (or 'reflection')" [18, p. 110]. Evidently, the concept of autopoiesis, as Luhmann later emphasises, is of "poor explanatory force" [13, p. 66] within the framework of a 'post-ontological' social theory. It implies nothing other than the methodological instruction that "all explanations have to start with the specific operations which reproduce a system" and accordingly "one has to study the system itself and not something other" [ibid]. In fact, by employing "autopoiesis" as method Luhmann succeeded in delivering the first convincing description of the relationship between the self-reference and the external reference of social systems.

According to Luhmann, social systems are self-referential ("autopoietic"), cognitively open, but operatively closed systems. Systems are not thought to depend on environment, they operate through communication. "Communication is ... autopoietic in that it is generated only within the recursive context of other communications, that is, only within a network that is reproduced by each particular communication" [13, pp. 82/3]. Building upon itself, communication makes it possible for systems to observe themselves and their environment in the social, temporal, and objective dimensions of meaning. "Everything that is experienced as reality", writes Luhmann, "comes out of the resistance of communication to communication" [13, p. 95]. Step by step, building upon what came before, communication produces society, the social produces the social. Operative closure means that systems are incapable of directly influencing one another. Cognitive openness means that they can be irritated by their observations of the environment.

\footnotetext{
${ }^{2}$ Disciplines such as cognitive biology, social anthropology, cybernetics and logics as well as other sources. Beyond the well popularised names of $\mathrm{H}$. Maturana for the concept of autopoiesis, G. Bateson for the intricacies of communication, and G. Spencer Brown for Luhmann's logics of form, one should also mention E. Husserl's phenomenology for the concepts of sense and time, G. W. F. Hegel for the theme of "world society", and H. von Förster for Luhmann's "radical constructivist" epistemological approach.

3 As is well known, Luhmann detaches the concept of communication from the idea of information spreading. In contrast to classical theories of information and coding, meaning cannot be exchanged in an interplay between sender and receiver, but depends on communication. Communication is an emergent reality sui generis. It has no subject(s), it happens. If it happens, it constitutes a social system which in its own observing (of itself, of other systems, or the world) is autonomous, but not autarkic. Social Systems rely fundamentally on a natural world. Nonetheless, this dependence does not determine the evolution of society. Society expands and contracts as social systems communicate.
} 
The coexistence of observing systems increases their mutual irritability. But the labour of transforming irritation into information that can be used within a system is an entirely internal affair of that system. No information is ever received; meaning is always newly constituted within a system and according to its guiding distinction ("code").

One example is the legal system. System's theory does not address the various configurations and entities which we are used to recognise positive law in, it understands law as a particular form of social communication [9, p. 147]. The analysis of this form is what Luhmann is interested in. The object is the difference between juridical communication and "otherwise orientated" communications [10, p. 341]. Juridical communications, guided by the distinction legal/not-legal, may be brought about by every one at any time and place. One participates in the legal system by using its system-reference to give meaning to one's activities. Thus, even the decision not to use the legal code is a decision within the system [17, p. 111]. Law is the comprehensive system of all juridical communications. Accordingly, its limits do not coincide with the limits of institutions and organisations or professional barriers. Not all social communications belong to the legal system, but any communication may place itself within the system.

Projecting the notion of autopoiesis onto society, Luhmann was able to concentrate on the inner side of systems and to state the rather general question of "What are the elements that make it possible for social systems to constitute themselves" more precisely: how it is possible that systems immanently, within themselves, produce not only self-references, but also external references-although there is from their own perspective no external point of view to take in order to produce such references? The analysis of communication paved the way for a convincing response. By including the dimension of time, Luhmann reached the decisive break-through. "Not the subject but time dissolving into events gives action its individuality" [14, p. 288]. What enables communicative events to build up systems is their transitoriness and continuous disintegration. Communicative systems are causality free zones. Integration/disintegration depends on time relations [13, p. 605].

The following years saw the application of general systems theory to important social spheres, i.e. the functional subsystems of society: economy (1988), science (1990), law (1993), art (1995)—each was described in its autonomy and particularity "as a social system"; volumes on politics (2000), religion (2000), and education (2002) have been published posthumously.

In 1997, Luhmann returned with Die Gesellschaft der Gesellschaft to the analysis of society as a whole and presented the theory in more detail and at a lower level of abstraction than in Social Systems. "The society of society", as the German title literally translates, highlights the fact that any understanding of society is produced by society itself. Society is a result of social self-description [13, pp. 15, 866f]. Selfdescription occurs when a social system observes itself as a unit, giving itself a name and naming what it is not, producing thereby a self-reflective narrative, an "autological" text [13, p. 880]. Society is whatever society itself constructs as society. As the society of society is communication, it does not make sense to speak of "societies" in the plural. 
Taking on again all these aspects and integrating them into the overall context of social theory, this (over 1,100 pages) long concluding chapter notably proves the conceptual transformations undergone by system's theory over the years. Luhmann had begun with thinking in differences instead of identities. Successively, the question of autopoiesis led him to the elaboration of a theory of observation (and the invention of a herculean hero called second order observer). At this stage, in the late 1980s and 1990s, the concept of meaning had moved into a foundational category which was undeniable, but also hardly identifiable. In an apparent effort to counterbalance the difficulties associated with these shifts Luhmann finally focussed on the concept of paradox [8] and tried ultimately to found his theory on it. But "Complexity can only be approached perspectively, and every advance varies more than it can control" [14, p. xlvii]—you can't go past it.

This brings us to our second point, because it is precisely this insight "where work" on a universal theory "begins" [ibid.].

\section{II}

Grundriss einer allgemeinen Theorie, "outline of a general theory": what does the subtitle mean? Is it a negligible ${ }^{4}$ piece of advice to the reader that what is to be expected in the book is a "comprehensive outline" of the author's "theoretical position" [14, p. xiv]? Does it refer to an ensemble of elementary reflections which are to be "viewed technically for constructing a theory" [14, n. 49]? So, should we take this as a rather modest subtitle? Or does it connect, with no false modesty, to a long line of famous predecessors-radically rejecting them? Could it have to do, for example, with what Bentham, distinguishing between "local" and "universal" legal science, called a "universal" jurisprudence "confined to terminology"; is it similar to Austin's "general jurisprudence" (in contrast to "particular" jurisprudence), "the science concerned with the exposition of the principles, notions, and distinctions which are common to systems of law"; does it correspond to what German legal theorists (such as Carl F. Gerber, Paul Laband, or Adolf Merkl) of the 19th century dealt with as the "Allgemeine Rechtslehre" (general theory of law) or Hans Kelsen, in 1937, as "pure theory of law" ?5 True, all these were jurists, not sociologists. But what counts here is certainly not disciplinary affiliation. Systems theory is more than traditional sociology. ${ }^{6}$ The point is that all of them considered themselves

\footnotetext{
${ }^{4}$ So perfectly so that editors of the English version had done well to protect at least English speaking readers from sheer redundancy by leaving out the subtitle?

5 An English version appeared in 1992 under the title "Introduction to the problems of legal theory". Following Kant's methodical approach, Kelsen tried to set out, first, a framework of fundamental concepts to apply, in a second step, to empirical, concrete material. Accordingly, he saw his "pure" theory as the theory of positive law tout court, applicable to all concrete legal orders.

${ }^{6}$ What holds for legal theory holds, mutatis mutandis, also for sociology. It suffices here to recall Max Webers's universalist design of a general sociology in Economy and Society. An outline of interpretive sociology, or Talcott Parsons' 'The Structure of Social Action which, according to Luhmann, is "the only systematic sociological theory that currently exists" $[13,21]$. "The keynote to be emphasized," Parsons writes in the Preface, "is perhaps given in the subtitle of the book; it is a study in social theory, not theories. Its interest is ... in a single body of systematic theoretical reasoning".
} 
scientists, not philosophers. What is common to all is the belief that scientific legal thinking is autonomous and has no need to learn from philosophy about what law is. Each of them was part of the reaction against a philosophical culture which in 1820 culminated in the eminent statement of the principles of legal, moral, social and political philosophy that Hegel published under the title "Grundlinien der Philosophie des Rechts oder Naturrecht und Staatswissenschaft im Grundrisse". I can't help reading Luhmann's humble subtitle as a pure declaration of war.

To claim universality means, according to Luhmann, that theory demands "to cover the whole realm of reality" of its object [16, p. 163]. Social theory deals with everything social, not just with particular spheres or local facts, and it wants to observe its object as it is. The theory's cognitive interest is the reality of society, and the description of the general structure of that object as a whole is its project. Furthermore: as social systems operate on the basis of the difference between environment and system, the whole world, as environment, is also included in the theory's universe of discourse. Finally: a universal theory cannot be but self-referential. Any understanding of the world is the result of social constructions, and theory as well [16, p. 164]. This fact determines a circular, seemingly paradoxical situation. Universal theories are related to itself as their own object [13, pp. 25, $1128 \mathrm{ff}]$. "The inclusion of the observer and of the instruments of observing within the realm of the objects of observation is a specific quality of universal theories" [16, p. 164]. Because systems theory can understand itself as a part of its object, it is a "self-supporting construction" [14, p. xlix]. As such, it must be "autologically" applied to itself (or otherwise surrender the claim to universality).

But the claim to universal validity does explicitly not imply that theory intended "to reflect the complete reality of its object" [14, p. xlvii]. Theory cannot claim "to exhaust all the possibilities of knowing its object" or even "demand exclusivity for its truth claims in relation to other, competing endeavours" [14, p. xlvii]. Of course, universal theories can be criticised as well as others "and, if needs be, ... integrated or substituted" [16, p. 165].

So one might be tempted to recognise in Luhmann's claim to universality a form of not making claims at all. Is it not expressing a certain form of modesty after all? Theory can assert no other than contingent truths. Whatever is presented as knowledge represents a view from a particular perspective, and therefore cannot be asserted as being better knowledge than other knowledge. All ends up in substituting the "opaque complexity" of the world for what appears from the observer's point of view as "transparent complexity" [14, p. xlvii]. The goal of 'mãllon eidénai', better seeing, which theory pursued ever since Aristotle, is an obsolete goal. Is "general theory", the only one that counts, still possible? What marks the difference between "theory" and any Weltanschauung? Lacking "confidence in words, even in the distinction verba/ res", as the late Luhmann sums up, one must give up the goal of a "paradox free science" [11, p. 256].

But not making substantial claims is not making no claims at all. Sociology failed to produce "even a partially adequate theory of society" [13, p. 17]. No genuine progress has ever been made toward constructing a scientific theory of society, Luhmann asserts. ${ }^{7}$

\footnotetext{
7 The false premises of prevailing sociological reasoning are that society (1) consists of human beings,
} (2) is constituted or at least integrated through consensus and shared values and interests, (3) is a 
The way out of the contingency problem does not consist in avoiding it by either not raising it at all and abandoning the claim to universal validity or by bypassing it and acknowledging a plurality of worlds. "The constraint that justifies [for systems theory, C.M.] the title 'theory' lies in the nonarbitrariness of its involvement with selfreference" [14, p. xlviii]. Theory cannot end with better (truthful) knowledge, but one can "let finish theory with a ... better difference" [16, p. 127]. Theory has to be considered solely in respect of its form. What makes the difference is method: it may happen that theory makes false statements, but, to be a good theory it must guarantee "at least" that its observations are "correctly false" [16, p. 150]. One might err, that's human after all. But, as a scientist, one has to ask the right kinds of questions: "Do it differently, that is the invitation, but do it at least as well" [13, pp. 1095, 1133]. But even a theory that passed the exam of this grand finale with distinction would, as observation, lag behind events: "Theory has not the last word. If it succeeds as a communication, it alters the society that it had described, alters thereby its object, and is accordingly no longer correct" [15]. At the heart of Luhmann's enterprise is a claim for a coherent scientific, ethical and political praxis which attempts to dismantle all foundational thinking.

\section{III}

Luhmann characterises his enterprise as "radically anti-humanist, radically antiregional, and radically constructivist" [13, p. 35]. He seeks to distance it from competing scientific and philosophical theories which attempt to describe their object in terms of normative, integrative, and unifying concepts. For this type of theory, and the whole tradition of occidental philosophical thinking, Luhmann has invented the label "old Europe". In "Old-Europe", the "tradition of rational knowledge and action sought after final foundations, after principles, after unquestionable maxims. If one wanted to continue the tradition, one would have to deliver a self-description of society and assert: this is the right one" [13, p. 1134]. His declaration of war is addressed to this cut-out target. But, in truth, his difference from the tradition of western thinking is far from being as radical as Luhmann staged it. In conclusion of this introduction, I will not try to answer the question whether Luhmann himself was, in secret, a philosopher or rather a philosophical amateur. Certainly, only a few German theorists of his generation were as well versed in philosophical tradition and semantics, and fewer still dealt with it in a similarly creative manner. But how does Luhmann's theory story link, connecting or breaking, to the tradition of occidental philosophy?

Is what is "new" ("original") in Luhmann the now vacant place of the traditional "subject" which Luhmann no longer wishes to speak of? Is this vacancy a lacuna, the place of hidden knowledge, in the sense of Alfred Schütz? The subject, or so it seems, is reappearing in the guise of the second order observer who has the qualities of the classical subject. He seeks to dissociate from any contingency, but he can't

Footnote 7 continued

regionally or territorially bounded unit (so that Italian society differs from German society), (4) can be observed therefore, like groups of people or territories, from the outside [13, pp. 24-25]. 
keep distance, he is a no-body without any extension, the almost mathematical point of attribution of operations, and he is a reflexive observer: he is a subject that could not be more firmly rooted in the philosophical tradition.

On the other hand, systems theory acquires and maintains its dynamic character from the fact there is no need for conceptual substitution of the subject. Method: the autopoiesis principle can prevent theory from seeking to pronounce a last word. Didn't the naivety of philosophy consist in the very trust in last foundations? But none of its ultimate concepts has ever been unsurpassable. The passing has always been a reconditioning of an ultimate concept by another one meant to be the last word. However, such philosophical moves have to do not so much with naivety as with modern philosophy's inescapable claim to itself to be theory, namely the one universal theory that can't tolerate others alongside. In this respect, Kant's explanation is still exemplary. Concerned with the apparent anarchy of philosophical doctrines which describe themselves as definitive "philosophical systems", Kant wonders "whether there could really be more than one philosophy" and responds that

anyone who announces a system of philosophy as his own work says in effect that before this philosophy there was none at all... If, therefore, the critical philosophy calls itself a philosophy before which there had been no philosophy at all, it does no more than has been done, will be done, and indeed must be done by anyone who draws up a philosophy on his own plan” [3, p. 36/37].

Accordingly, what appears to be naive is not the claim to universality, but the idea that there could be ever a last, concluding word to support a given architecture. In the words of Jacques Derrida who seems to join Kant here: "Le système de toute connaissance philosophique, voilà ce qu'on appelle la philosophie. C'est la simple idée d'une science possible, elle n'est donnée nulle part in concreto. On ne peut donc que se trouver en chemin vers elle" [2, p. 368].

Luhmann however has never developed a language in which he could reflect on the philosophical meaning of his own enterprise. What characterises his position certainly is the attempt to resist to the temptation to pronounce a final word. But this fact does not mark a difference. On the contrary, it marks the fact of Luhmann's stride on the overgrown path of critical European thinking. So, wherever you might place him, Luhmann is and will be, our Luhmann.

\section{IV}

All of the essays in this Special Issue address the question of how legal communication operates in constituting the unity, logic and function of what is observed as legal system. In exploring that question, and in asking just what law (that is, according to Luhmann, the unity of the difference between law and not-law) means, each contribution focuses on a specific immanent (systematic) and transcendent (critical) context.

The thematic horizons of the four contributions to this collection are time, justice, decision and autopoiesis. In their sequence, contributions move from a focus on the analysis of the legal system's inside to an outside perspective. They start by 
exploring Luhmann's treatment of the legal system as a causality free zone and conclude with questioning its presentation as a context free zone. Systematically they go from legal theoretical considerations to ethical and epistemological reflections.

The essays describe law and its internal and external boundaries from different perspectives and with reference to different questions. The first contribution, focussing on law's construction of time, explores the relationship of time and justice. The relationship between law and justice is then further tracked through a comparison between Luhmann's seemingly formal conception of justice and alternative, rather substantially oriented approaches. Succinctly, Luhmann's argumentation concerning the role of decision within the legal system is connected back to traditional legal argumentation first and then shown to be merging epistemological with ethical aspects. The critique raised here is radicalised in the concluding chapter which, exploring the issue of materiality, aims to discover the dark side of autopoietic theory.

Given that these contexts, and the modes of law's functioning which they disclose, are rather varied, this issue is quite apart from providing a general account of Luhmann's legal theory or, at least, an appreciation of Luhmann's theoretical achievement. But, diverse as they may be, our approaches are brought together as resources for reflection upon specific questions posed or disregarded by Luhmann's law. Collectively, the contributions to this volume give systematic and comparative depth to reflection on the role of law within modern society.

Richard Nobles and David Schiff's essay explores the connection between the temporal dimension of meaning within the legal system and its connection to justice. The argument is about the construction of time and justice within the legal system. In other words: how is the distinction before/after produced and used in legal communications, and how is, within the legal system -the system of all legal communications- "time" related to what the same system constructs as "justice". The general question here is of the legal system's self-description. The paper explores two major but distinct examples. The first is the temporality of judicial decisions. In creating this temporal dimension of meaning, law has to make its selections through a process of 'treating like cases alike', a process in which, according to Luhmann, the formula for contingency is justice. The second, substantive example concerns the relationship between the temporal meaning of law's operations, and the presumption of innocence. Here, the focus is on the temporal meanings generated by law's interpretations of its communications as acts, and precisely as decisions. By marking the eigenvalue of justice within the legal system, the notion of presumption of innocence represents law's temporality. And it also explains how the (procedural) practice of law that appears to incorporate legal values and principles depends on that temporality.

There is however a further question pointed out by these examples concerning the self-description of law. Law cannot interpret its communications as decisions, without affirming that decisions make a difference. Decisions are not only selections, but they cannot be given the meaning of decision without this also having a temporal dimension, which is that whatever they decide had not been 
decided prior to the decision. This fact implies that law is law and not law at the same time.

Francesco Belvisi's essay is a study in the role of legal argumentation for Luhmann's construction of justice. It concerns a more comprehensive question than the one explored in the first contribution. Justice refers not only to the ways of just decision within the legal system. It poses the problem of a just organisation of the entire legal system. Is law as a whole, as Luhmann says, "adequately complex" to comply with modern society's demands for justice? Only in the case of a positive answer can one speak of legal justice. In the negative case justice has to be found beyond the law. So, the question of justice within and through the law leads onto the question of the possibility of justice. Belvisi's point of departure is the observation that law's justice programme, equality of treatment, hides the paradoxical request to treat equal cases equally and different cases differently. For this reason, justice cannot be understood only as consistency of decision, but implies adequate complexity towards the outside. Thus, not the single decision, but the entire legal system is constantly in need of interpretation and argumentation by generating redundancy: the solid ground of semantics and procedures, argumentation confers communicative authority to contingent decisions. This is how Luhmann defines the function of argumentation. There is a shift, Belvisi sustains, from justice as consistency to justice as redundancy, the former being placed in the inside perspective of legal operations and the latter being externally orientated to the (environmental) outside. Both levels are linked by argumentation. Consequently, Belvisi refutes Gunther Teubner's critique according to which Luhmann's theory of justice would "grasp only half the problem" of justice (namely its formal, but not the substantial side) as well as Teubner's remedy of a more responsive, selftranscending law. However, Belvisi also considers Luhmann's conception critically and deems it in need of an overhaul. Luhmann's blind spot seems to concern the "substantial difference" between Rechtsstaat (rule of law) and constitutional state. Today, Belvisi holds, principles like liberty, equality, solidarity, etc. are selfreferential "eigenvalues" of the (constitutional) law. Being necessarily underdetermined, constitutional principles introduce uncertainty into the legal system (hence their "pragmatic value" under the conditions of a contemporary pluralistic and multicultural society).

My own contribution explores what is apparently a non-topic for Luhmann. Luhmann is preoccupied with decision-making rather than with judgment. The essay argues that Luhmann presents the epistemological-ethical doublet of a "selfbinding" of the law. In this bootstrapping manoeuvre decision plays the central part. Decision is fundamental not only in the legal system, but in all social systems, and hence in systems theory itself. Luhmann's description of decision is decisive for systems theory's claim to be the paradigmatic theory. I begin by examining judgment in its relation to decision. From a sociological point of view, judging is a social practice. Judgment reveals a specific practical referencing to the world. Luhmann tends to misjudge the symbolic side as ornamental or even as mystifying trimmings of decision. From the point of view of legal theory, judgment involves several phases and spheres. The unitary process of unfolding judgment transforms its object. Luhmann's analysis of decision-making marginalises peripheral legal 
communication. The question of other dimensions, such as aesthetics or the political, inherent in legal communication, is left aside or denied. From a cognitive point of view, judgment is the construction of law. Deciding does not coincide with it. Luhmann, cutting out decision from judgment, puts the former down to distinction. Against that background the contribution unfolds the distinction between distinction, form and decision in systems theory. I then continue with a discussion of Luhmann's description of the role played by decision within the legal system. Luhmann's question is about the role played by distinction in the production of social systems. He has no interest in decision that would go beyond the factum brutum of its systemic production. The hypothesis is that Luhmann blends (overt) cognitive with (covert) ethical aspects. This view is supported by a short examination, in conclusion, of Luhmann's polemics against alternative approaches. Foundational claims, I argue, do not only orient Luhmann's critique of competing reality constructions, they lead him to derive ethical positions in an archphilosophical manner. The suggestion is that 'judgment', in Luhmann's systems theory, re-enters by the back door as an ethical-theoretical imperative that commands theory's responsibility for society and law.

Andreas Philippopoulos-Mihalopoulos's essay sketches another approach to the Luhmannian architecture of systems theory by descending into the autopoietic heart of the theory. Investigating the fundamental environment/system distinction that makes this heart beat, he detects that one ventricle is empty: in Luhmann's conception of autopoiesis, materiality is left outside, in the environment. So, matter as being has no place in the edifice, it can only appear as medium. This causes a fibrillation of the whole organ. Philippopoulos-Mihalopoulos's sketch of a "critical autopoiesis" can be seen as an attempt to recondition Luhmann's description by suggesting the substitution of the environment/system difference (as well as the implicit topology which derives from the boundary in between) by a system/ environment continuum. The question here is, how does matter contribute to the formation of sense? The essay elaborates this proposal by confronting systems theory with various approaches of a contemporary 'new materialism' and by opening it up primarily to Deleuzian thought. This seems promising because Deleuzian surface continuity between incorporeality and corporeality had appeared (but not been elaborated) in Luhmann under the name of materiality continuum. Philippopoulos-Mihalopoulos's claim that Luhmann 'dissimulated' matter in various ways holds true in particular in respect to law. Here, materiality seems to be absorbed by the black hole of communication. Luhmann's distinction based interpretation of autopoiesis commands a reading of legal communication as a form of representation of the outside within. But what is 'represented' in the system is nothing other than a construction of internal and external references. How then can materiality, and different kinds of legal materiality, find their way into the legal system? And, principally: if law is matter, then where is the locus of resistance to the law?

Acknowledgments A word of thank must go to Anne Wagner for the interest she displayed towards the project of this special issue and the patience and understanding which she accompanied it with, to Ronnie Lippens for his 'guinea pig' comments, and to the contributors for their endurance and cooperation. 


\section{References}

1. Deflem, Mathieu. 1998. The boundaries of abortion law: Systems theory from Parsons to Luhmann and Habermas. Social Forces 76(3): 775-818.

2. Derrida, Jacques. 1990. Du droit à la philosophie. Paris: Galilée.

3. Kant, Immanuel. 1991. The metaphysics of morals (1797), (trans: Gregor, Mary) Cambridge: Cambridge University Press.

4. King, Michael. 2001. The construction and the demolition of the Luhmann Heresy. Law and Critique 12: $1-32$.

5. King, Michael, and Anton Schutz. 1994. The ambitious modesty of Niklas Luhmann. Journal of Law and Society 21(3): 261-287.

6. King, Michael, and Chris Thornhill (eds.). 2006. Luhmann on law and politics: Critical appraisals and applications. London: Hart.

7. Kjaer, Poul. 2006. Systems in context. On the outcome of the Habermas/Luhmann-debate. Ancilla Juris. Online: http://www.anci.ch/_media/beitrag/ancilla2006_66_kjaer_systems.pdf. Accessed 26 June 2007.

8. Lau, Felix. 2005. Die Form der Paradoxie. Eine Einführung in die Mathematik und Philosophie der "Laws of Form" von G. Spencer Brown. Heidelberg: Carl-Auer-Systeme.

9. Luhmann, Niklas. 2004. Law as a social system (trans: Ziegert, Klaus A.). Oxford: Oxford University Press [or. Das Recht der Gesellschaft. Frankfurt: Suhrkamp, 1993].

10. Luhmann, Niklas. 2002. Die Religion der Gesellschaft. Frankfurt: Suhrkamp.

11. Luhmann, Niklas. 2001. Die Paradoxie der Form. In Aufsätze und Reden, ed. Oliver Jahraus, 243-261. Stuttgart: Reclam (or. in: Kalkül der Form, ed. Dirk Baecker, 197-212. Frankfurt: Suhrkamp, 1993).

12. Luhmann, Niklas. 2000. Art as a social system. Stanford: Stanford UP.

13. Luhmann, Niklas. 1997. Die Gesellschaft der Gesellschaft. Frankfurt: Suhrkamp.

14. Luhmann, Niklas. 1995. Social systems (trans: Bednarz, John Jr. and Dirk Baecker). Stanford: Stanford University Press [or. Soziale Systeme. Grundriss einer allgemeinen Theorie. Frankfurt: Suhrkamp, 1984].

15. Luhmann, Niklas. 1988. Njet-Set und Terror-Desperados. taz, August 4, 1988.

16. Luhmann, Niklas. 1987. Archimedes und wir. Interviews. Berlin: Merve.

17. Luhmann, Niklas. 1986. The self-reproduction of law and its limits. In Dilemmas of law in the welfare state, ed. Gunther Teubner, 111-127. Berlin: De Gruyter.

18. Luhmann, Niklas. 1986. Was ist Kommunikation. In Soziologische Aufklärung, Vol. 6, 109-120. Wiesbaden: VS Verlag für Sozialwissenschaften, 2005.

19. Merz-Benz, Peter-Ulrich, and G. Wagner (eds.). 2000. Die Logik der Systeme. Zur Kritik der systemtheoretischen Soziologie Niklas Luhmanns. Konstanz: UVK.

20. Reese-Schäfer, Walter. 1992. Luhmann zur Einführung. Hamburg: Junius.

21. Schwanitz, Dietrich. 1999. Bildung. Alles, was man wissen muss. Frankfurt: Eichborn.

22. Thornhill, Chris. 2002. Systems theory and legal theory: Luhmann, Heidegger and the false ends of metaphysics. Radical Philosophy 116: 7-20.

23. Vandenberghe, Frédéric. 1999. Systemic supertheorist of the social: Niklas Luhmann, 1927-1998. Radical Philosophy 94: 54-56.

24. Weinberger, Ota. 2000. Neo-Institutionalismus versus Systemtheorie. In Die Logik der Systeme. Zur Kritik der systemtheoretischen Soziologie Niklas Luhmanns, ed. Peter-Ulrich Merz-Benz, and G. Wagner, 305-326. Konstanz: UVK. 